\title{
Business Coordination and Tax Politics
}

\author{
Néstor Castañeda* \\ University College London \\ n.castaneda(a)ucl.ac.uk
}

Forthcoming, Political Studies

\begin{abstract}
Business interest groups are crucial actors for tax policy-making, but it is still unclear under which conditions they are more successful than politicians in shaping taxation. This article argues that centralized coordination and high-levels of policy integration make business interest groups more influential in the tax policy-making process. If there is no ideological convergence between agenda-setters and business, highly centralized, and well-integrated business interest groups are more successful in blocking or softening revenue-raising tax reforms, or simply transferring tax burdens to consumers or non-organized citizens. To evaluate this theoretical framework, I have compiled an original data set on business groups and associations for 18 countries in Latin America between 1990 and 2010. This theory uncovers a strong link between the patterns of business coordination and the feasibility of implementing distributive tax policies. This article also contributes to the study of business politics beyond the limited sample of developed countries.
\end{abstract}

Keywords: Tax Politics, Business Interest Groups, Latin America

\footnotetext{
${ }^{*}$ Assistant Professor in Latin American Political Economy, University College London. The author would like to thank Aníbal Pérez-Liñán, Barry Ames, Scott Morgenstern, David Doyle, Cassilde Schwartz, and two anonymous reviewers of Political Studies for their helpful advice and constructive feedback on previous versions of this article. Previous versions of this article were presented in the MPSA Annual Conference 2014, the ECPR Annual Conference 2014, the PSA Annual Conference 2015, and the EPSA Annual Conference 2015. The author would also like to thank for the feedback received from discussants and participants in those conference panels.
} 


\section{Introduction}

The increasing volatility of international financial markets and international commodity prices has substantially raised the level of fiscal stress for governments in developed and developing countries. Central governments not only face growing political pressures to raise social expenditures, but they also have limited policy tools available to manage fiscal policy. Access to external debt is more restricted than some decades ago ${ }^{\boxplus}$ and the use of monetary policy to fund governments is now less common. Some governments have access to extraordinary natural resources revenues; however, the increasing volatility of international oil prices can call into question the sustainability of a fiscal policy based on oil revenues. Consequently, tax reforms are unavoidably the main ingredient of any fiscal deficit reduction plan.

Comparative politics literature has investigated the politics of tax reform by focusing on the role of political and economic institutions (Poterba and Von Hagen 1999; Persson and Tabellini 2003; Rodden 2006; Hallerberg, Scartascini, and Stein 2009), the government?s ability to capitalize crisis environments (Alesina and Drazen 1991; Mahon 2004; Fisher 2009; Alt, Preston, and Sibieta 2010), and the bargaining between agenda-setters and legislators (Schick 1980; Profeta and Scabrosetti 2008; Richter, Samphantharak, and Timmons 2009). Yet this work does not provide a full account of the variation in the implementation of revenue-raising tax reforms because it overlooks the role of the most important actors in tax policymaking: business interest groups. Firms and business organizations play an obvious and central role in fiscal policymaking, but their role has not been systematically analyzed, especially in the context of developing countries (Smith et al. 2014). Scholars and pundits simply argue that money buys influence, or that business interest groups have hijacked democratic governments. However, there have been very few attempts to understand the

\footnotetext{
${ }^{1}$ External debt to GNI ratios of developing countries fell down substantially since the 1980s (World Bank 2011). For a long-term empirical analysis of external and domestic public debt in developing countries please see Reinhart and Rogoff (2011)

${ }^{2}$ Please see Cartens and Jacome (2005)

${ }^{3}$ Please see Collier and Venables (2011)
} 
mechanisms that effectively translate business influence into specific policy outcomes, or under which particular conditions business are more successful than politicians and technocrats in shaping policies (Baumgartner et al. 2009, Culpepper 2011, Fairfield 2015).

In contrast, this article highlights the importance of business interest groups for the analysis of tax policymaking. In particular, I argue that cross-country variation in tax revenues mainly depends on the interaction between the policy preferences of the agenda-setter (presidents and/or finance ministers) and the domestic patterns of business coordination. I develop a theory that builds from the existing literature on varieties of capitalism and business interest groups (Hall and Soskice 2001; Martin and Swank 2004; Culpepper 2011; Schneider 2013) and incorporates the patterns of business coordination as a crucial factor in explaining fiscal policy. I argue that centralized coordination and policy integration jointly make business interest groups more effective for lobbying activities, and consequently, more influential in shaping tax policy.

The rationale of the theory is straightforward. Agenda-setters (presidents and/or finance ministers) and business interest groups have distinctive preferences over types of taxation (direct vs. indirect), tax rates (corporate, income, value-added taxes, etc.), and special provisions (i.e. tax deduction, tax credits). For the agenda-setters, these preferences are usually partisan-oriented or simply depend on the characteristics of the government coalition. For example, left-wing governments usually extract higher levels of tax revenues to finance distributive social programs, and right-wing governments collect fewer taxes in order to promote private investment and stimulate economic growth (Boix 1998, 11).

Meanwhile, business usually prefers low corporate tax rates, and its preferences about personal income and value-added taxes are generally more ambiguous. These preferences are usually subordinated to their market strategies and their sources of comparative advantage regarding potential competitors (Culpepper 2011; Schneider 2013). Consequently, under some circumstances, business will lobby against increasing personal income tax; but under other circumstances, they would support increases in personal income tax. 
These actors' preferences are obviously consequential for tax policy, but only under particular institutional and organizational settings. Consequently, I argue that revenue-raising tax reforms are most likely to occur if there is discord between business and agenda setters' preferences, and the resulting tax policy will depend on business groups' organizational capacity (varying from centralized to decentralized coordination) to curtail the effect of the agenda-setters' policy preferences.

I test this argument for a sample of Latin American countries between 1990 and 2010. This is a very relevant sample for two reasons. First, the countries selected are all middleincome, allowing for variance in the level of economic growth, economic diversification, and business organizational capacity. Second, these countries are all presidential regimes, for which there is a clear identification of agenda-setters' preferences. Because some of the relevant data are not available for this a sample of countries, I built an original database of business organizations in 18 Latin American countries between 1990 and 2010. These data were collected from institutional archives, personal visits to business associations, and interviews with business' representatives and policy experts. The resulting dataset is unique source for a region characterized by low levels of data transparency, lack of information about lobbying, and almost non-existent data on interest groups (see Appendix for more information).

Overall, this analysis finds strong support for the existence of a systematic link between the patterns of business coordination and tax policy, challenging the widespread argument that agenda-setters in Latin America are the dominant actors in fiscal policy-making. These findings enrich political-economy theories of democratic governance by modeling the role of business interest groups in policy-making and its implications for policy change. Therefore, this article not only offers an innovative way to analyze the sources of business power of influence, but it also offers a new theoretical approach for the analysis of tax reforms. Finally, this article also makes an important contribution for the study of business politics beyond the limited sample of developed countries. 


\section{Business Coordination and Tax Policy}

Literature on special interest groups has long noted that the distribution of the tax burden reflects the distribution of power among societal groups and the variation in their policy preferences (Bartlett 1973; Salamon and Siegfried 1977; Wilson 1983; Hettich and Winer 1988; Steinmo 1989). This literature suggests that state actors and their preferences play a crucial role in public policymaking, and consequently, different constitutional and electoral structures explain the cross-regional variation in tax systems (Hettich and Winer 1988; Steinmo 1989). For example, Steinmo (1989) demonstrates that the structure of decision-making has definitively shaped tax policy in Britain, Sweden, and United States. Similar arguments are quite common among scholars studying decision-making process in Latin America (Spiller and Tommasi 2007; Stein and Tomassi 2008). This institutional perspective does not ignore interest groups, but put them in a second level of analysis. These scholars are usually more interested in the institutional background in which people make decisions.

Most recently, some scholars have paid more attention to the role of interest groups in decision making and argue that the variation in the patterns of interest groups' internal organization seem to have substantial effects on the implementation of welfare, social, and economic policies in western democracies (Martin and Swank 2004; Culpepper 2011; Schneider 2013). Similarly, scholarship on varieties of capitalism also shows that different patterns in the organization of capital and its relationship with labor sectors affect public policy outcomes (Rueda and Pontusson 2000; Schneider 2013). This literature finds that business interest groups can influence policy making not only if they can afford to do it, but also if they are able to solve internal free-rider problems. For example, Martin and Swank (2001, 2004) have demonstrated that the organization of employers - the so-called social corporatist organization of business - shapes social policy support among firms and make them more prone to support redistributive social programs. In fact, they show that the "centralization and coordination of employers as well as the integration of employer organizations in corporatist policy-making forums are strongly associated with shares of national income devoted 
to active labor market policy" in western democracies (Martin and Swank 2004, 593).

While the influence of business interest groups in policy-making process is incontrovertible, its policy consequences are ambiguous, and its causal mechanisms are understudied. We know that money buys influence (de Figueiredo and Ritcher 2013) and that the patterns of business organization matter (Martin and Swank 2004). However, we know very little about the organizational attributes that make business interest groups more or less influential in the policy-making process and the causal mechanisms that transform such influence into specific policy outcomes.

Based on Martin and Swank (Martin 1991; Martin and Swank 2004; Swank and Martin 2001), I propose a theory of policy change that focuses on business coordination to explain variation in tax policy. This theory models business groups' political action as a "reactive" strategy that is only triggered when their policy preferences contrast with those of the agenda-setter and depends on their internal capacity to coordinate political influence activities.

Let me explain the rationale of this theory. The agenda-setters (i.e. presidents or finance ministers), as the first movers in the policy-making process, have an advantage in fiscal politics: their policy preferences set agenda priorities (Cox and McCubbins 2005). The agenda-setters' policy preferences might be categorized into two ideal types: some agendasetters could be classified as taxers if their most preferred fiscal policy is to increase tax burdens (rather than reduce expenditures); meanwhile, some agenda-setters could be classified as non-taxers if their most preferred fiscal policy is to reduce expenditures (rather than increase tax burdens). ${ }^{-1}$ In general, these policy preferences reflect their partisan linkages and the alliances they make during and after electoral campaigns.

Obviously, the agenda-setters' preferences are not exogenous to the political or economic context. Indeed, their preferences might be very different if the central bank is not independent from the central government (the government might have unusual access to domestic

\footnotetext{
${ }^{4}$ Fiscal deficit is not a credible policy option because it is not sustainable in the long term and implies high political costs for the agenda-setters (Alesina, Carloni, and Lecce 2011).
} 
and/or external debt) or if there is an extraordinary availability of natural resources (i.e. oil or natural gas). However, these policy alternatives could be considered exogenous distortions rather than deciding factors in the fiscal policy game. Thus, when facing fiscal stress situations, the agenda-setters are constrained to choose between more taxes or less expenditures as the main policy tools to attain fiscal balance.

Evaluating the role of the agenda-setters in the fiscal policy-making process also requires assessing their capacity to transform preferences into actual policies (i.e. their capacity to pass legislation in congress). I will refer to this capacity as partisan power. That is, the extent to which the agenda-setter controls their own party (or legislative coalition), and whether or not their party (or legislative coalition) has a majority of seats in congress (Mainwaring and Shugart 1997, 40). Thus, we might contend that if the agenda-setters' party (or coalition) has too few seats in the legislature or is highly fragmented it will be more difficult to transform preferences into actual policies (Mainwaring 1993).

Now, let us examine the business-side of the fiscal policy game. Research on the role of business interest groups in fiscal policy-making is still very limited (Coen, Grant, and Wilson 2010) and does not offer any parsimonious explanations about the factors that make business more or less influential. Traditional scholarship argues that there are two types of political power that enable business to influence the policy-making process: structural and instrumental power (Miliband 1969; Lindblom 1977). From this perspective, the political influence of business interest groups depends on their capacity to withhold investment and lower economic growth - structural power - (Lindblom 1977), and their financial capacity to spend resources in political actions like lobbying, campaign spending, or informal networking - instrumental power (Miliband 1969). ${ }^{\text {[ }}$

This scholarship provides useful insights into the dynamics of business political influence, but it overlooks the effect that different models of business coordination could have on the

\footnotetext{
${ }^{5}$ Any focus on constitutional powers (e.g. veto, partial veto, or decree powers) would be disadvantageous because the real effect of such constitutional instruments cannot be accurately measured from a comparative perspective (Metcalf 2000).

${ }^{6}$ Fairfield (2015) uses this framework to explain recent tax reforms in Argentina, Bolivia, and Chile.
} 
relationship between business and government. In other words, this literature does not recognize that the internal structure of business organizations shapes not only their policy preferences and strategies, but also policymakers' preferences and actions.

For example, in centrally coordinated business environments, business interest groups are usually more focused on broad and collective goals, and encompassing associations concentrate major representational power (Martin and Swank 2004; Martin and Swank 2012). These encompassing associations are also generally well integrated to policy-making forums and have access to pivotal actors in the policy process.

In contrast, in decentralized business environments, business interests groups are usually more focused on particularistic policy goals and resources available for lobbying activities are less predictable (Martin and Swank 2004; Martin and Swank 2012). Their level of integration to policy-making forums and their access to policymakers also vary substantially from one economic sector to another. Consequently, business will focus their lobbying efforts on particularistic issues and will spend more resources in legislative lobbying, only because it is relatively inexpensive and individual legislators are more responsive to tangible benefits (Grossman 2002).

Consequently, revenue-raising tax reforms will be less likely in the presence of highly coordinated and centralized business associations because, unlike decentralized business interest groups, they can effectively attenuate the influence of the agenda-setter's preferences on tax policy outcomes. If the agenda-setters and business interest groups have similar tax policy preferences (e.g. the president and the finance minister are not taxers), tax reform will be limited because neither of them is interested in altering the tax structure. However, if there is no policy convergence (e.g., president and the finance minister are taxers), the agenda-setters will propose tax increases and business will seek to block such initiatives, or at least to avoid increases in corporate taxation.

If business interest groups are centrally coordinated, they will have substantial leverage and organizational resources to block tax reform bills in congress, or even before, when 
technocrats draft them. Even if the agenda-setters strongly prefer to increase taxes, the presence of highly coordinated business will attenuate their effect on tax policy.

If business interest groups are not centrally coordinated (sector coordination or decentralization are predominant), they will not be well integrated to policy-making forums and their organizational/financial resources will be relatively low (or, at least, the availability of financial resources will vary across different industries). Consequently, business interest groups will be less able to block tax reform initiatives and they will be only able to reduce potential impacts on specific industries (those industries with most resources available for lobbying).

Therefore, this theory of tax policy change suggests that cross-country variation in tax policy is a conditional function of the domestic patterns of business coordination (centralized coordination vs. decentralized/non-coordination) and the agenda-setters' tax policy preferences. In other words, the agenda power of presidents and finance ministers is always conditional on the level of internal organization of de-facto veto players like business interest groups.

This theoretical framework allows us to predict feasible tax policy outcomes based on the attributes of institutional and non-institutional veto players (Table 1). Therefore, one can hypothesize that structural tax reforms will be possible only if: i) the agenda-setters (presidents or finance ministers) strictly prefer increasing taxes over cutting spending; ii) they have strong partisan powers to promote policy change; and iii) business interest groups are neither centrally coordinated around encompassing organizations nor well integrated to the policy-making process. In other words, direct tax burdens will increase (especially corporate taxes) only if the agenda-setters are taxers, they have strong partisan powers, and business interests groups are not centrally coordinated (panel II).

If the agenda-setters are taxers and business interest groups are centrally coordinated, tax reforms will range from minimal to partial (as the agenda-setters' partisan powers increase) and the likelihood of higher indirect taxes will increase substantially (panels IV and V). 
Under this scenario, highly coordinated business interest groups would successfully fight government's attempts to increase corporate tax rates, and the government will be compelled to finance its expenditures with indirect taxes (e.g. value-added tax) or non-traditional taxes (e.g. gasoline or financial transaction taxes). In some cases, business interest groups would also support increases in personal income tax rates as it reduces the pressure on corporate taxation.

Table 1: Feasible Tax Outcomes

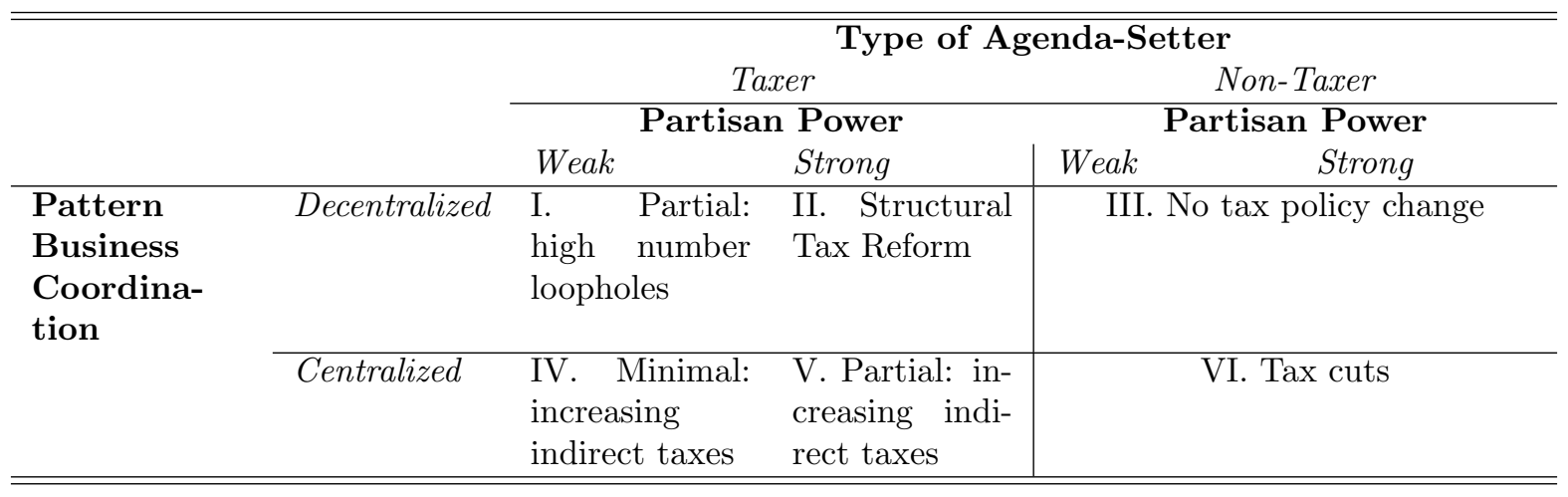

If the agenda-setters are non-taxers (i.e. business and government have similar tax policy preferences), tax reforms will not be likely (panel III). In fact, under these circumstances, if business interest groups are highly coordinated, they could actually promote substantial tax-cuts (panel VI).

In sum, this theory of policy change suggests that agenda-setters' policy preferences are not the only factor shaping tax policy. It is also a function of the domestic patterns of business organization (centralized coordination vs. decentralized/non-coordination). In other words, there are models of coordination that make business more successful than politicians in the legislative process and more successful in transferring the tax burden to non-organized or less-organized groups of citizens. 


\section{Data and Methods}

To analyze the capacity of business to curtail agenda power in tax policymaking, I build a unique panel dataset on business interest groups in Latin America between 1990 and 2010. These dataset includes original data on basic organizational features of business associations like centralization, membership, age, and integration to policy boards. It also includes data on taxes, including total tax revenues, direct and indirect tax revenues for all the countries in the region (Table 1 in the Appendix presents basic descriptive statistics).

The first outcome variable measures cross-country variation in tax-to-GDP ratio in Latin America between 1990 and 2010. The second outcome variable measures cross-country variation in direct and indirect tax revenues in Latin America between 1990 and 2010. Data on cross-country variation in general tax burden (\% GDP), and direct and indirect taxation (\% total tax revenue) are based on official statistics collected by the Statistics Division of the United Nations - Economic Commission for Latin America and the Caribbean (ECLAC).

As suggested in the theory section, the main explanatory variables of interest are the agenda-setter's fiscal policy preferences and partisan powers, and the degree of internal business coordination. Abundant literature in comparative political economy suggests that right-leaning presidents are more fiscally conservative than left-leaning presidents (Alesina and Rosenthal 1995; Boix 1998; Johnson and Crisp 2003). Thus, one could assume that ideological scores are a good measure of the agenda-setters' policy preferences. However, these scores have two problems. On one hand, the most commonly used data on Latin American presidents' ideology estimate their economic policy preferences based on partisan rather than actual policy positions. On the other hand, conventional ideology scores do not take into account the frequency by which politicians switch their policy preferences after elections (Stokes 2001) and the fact that partisan differences on tax policy issues are less clear than we might think (Hart 2010; Castaneda and Doyle, 2015). For example, it is common that rightist presidents are less fiscally conservative than leftist presidents and vice-versa.

\footnotetext{
${ }^{7}$ For example, the Social Democrats (leftist party) in Chile are the regional model for responsible fiscal
} 
In order to distinguish between the agenda-setters' ideological preferences and their actual tax preferences, I built an index of fiscal policy preferences based on existing datasets (Coppedge 1997; Huber et al. 2012; Murillo, Oliveros, and Vaishnav 2010) and also original data I collected in the field. After compiling information from multiple datasets and filling in missing data, I coded the agenda-setters (presidents and finance ministers) in the region as taxers and non-taxers according to their actual willingness to introduce tax reform initiatives when they were in office. This coding also relies heavily on press review and third-person assessments.

For the agenda-setters' partisan powers, I calculated the percentage of seats held by the president's party (coalition) in the lower chamber of congress. In this case, I rely on data provided by Pérez-Liñán (2013) on the size of coalitions and factions within the legislative bodies in Latin America from 1945 to the present.

The theoretical framework also contends that business interests are more influential as they become more centrally coordinated around encompassing associations, and they are better integrated to policy-making boards. As business interest groups become more centrally organized and coordinated, they tend to develop political positions that transcend narrow or particularistic demands of individual firms or sectors and focus on broader collective concerns; consequently, they tend to be more influential in public policy-making. Additionally, centrally coordinated business interest groups tend to be better resourced for lobbying and have a more relevant presence in decisive policy forums. ${ }^{\mathbf{x}}$

Based on these considerations, I built a two-component typology of business coordination that combines the concepts of business centralization and policy integration to assess the business interest groups' potential capacity to influence the policy-making process. For the first component, I use the classic measure of business centralization, which evaluates the governance in Latin America. On the contrary, conservative governments in Mexico (i.e. Calderon 2006-2012) and Colombia (i.e Pastrana 1998-2002) have been very harmful for fiscal governance.

${ }^{8}$ It is possible that a business association could be highly centralized but weakly resourced, but those cases are exceptional. In the data collected for this project, I found very few cases where highly centralized and coordinated associations were weakly resourced. Interviews in the fieldwork confirm this evidence. 
extent to which there are encompassing associations that represent major industrial sectors. This is a dichotomous variable with values of one if there is at least one national-peak business association that represents the interests of the three-main sectors of the economy, and values of zero if there is no national-peak association, or if there is one, it does not include the three main sectors of the economy. In this case, I rely on original data that I collected from press review, fieldwork interviews, and short-surveys with policy experts and staff members of the main business associations in every country included in the analysis.

For the second component, I built a measure of policy integration with values of zero (low bargaining authority) if the encompassing business associations have no role on important policy boards or the agreements reached by business and government are non-enforceable. This measure takes values of one (high bargaining authority) if business monopolize policy bargaining and the agreements between government and business are enforceable. Let me explain this with more detail.

The mere existence of encompassing business associations does not guarantee policy influence if these organizations have limited access to decisive policy-making arenas. Therefore, we also need to evaluate whether encompassing business associations meet regularly with government and labor representatives, and whether or not they are active members of decisive policy-making committees. That is, we should assess 1) whether or not there are centralized mechanisms for market coordination (Iversen 1999), and 2) whether or not business interests are active players within these bargaining institutions (Wallerstein, Golden, and Lange 1997; Iversen, Pontusson, and Soskice 2000). Business interest groups usually participate in different policy commissions/boards. Some of these policy boards are significant for policy purposes; others are not. From a comparative perspective, it is difficult to pick just one policy board or forum like the most meaningful one to assess the overall integration of business into the policymaking process. However, in Latin America, some policy boards/forums are definitively more relevant than others. In particular, there has been a long tradition of negotiating minimum wages in this "corporatist" fashion in the region 
(Murillo 2001) and tripartite commissions (business-labor-government), created to set minimum wages in the early stages of the industrialization process, are still important forums of cooperative engagement between employers, labor, and government. For this reason, these wage-bargaining institutional mechanisms are quite relevant to measure of the degree to which business interest groups are integrated to the national-level policy-making process.

Consequently, I collected information about the wage bargaining process for all countries in the region and identified whether the minimum wage targets are usually defined exclusively by the national government (without any consultation with business or labor), or by advisory committees (boards/forums) including representatives from the government, labor unions, or business associations. I also evaluated whether or not such business associations are pivotal players in these committees (boards/forums). Finally, I investigated if the minimum wage targets set by these committees (boards/forums) are enforceable or not. I collected this information directly from newspapers and current events magazines for every country in the region for the period 1990-2010.

As mentioned above, our typology of business coordination combines both business centralization and policy integration. This typology consists of three categories: i) decentralized coordination: if business interests are coordinated only at the sector/industry level and they have low bargaining authority; ii) weakly centralized coordination: if business interests are centrally coordinated but their bargaining authority is low; and iii) centralized coordination: if business interests are centrally coordinated and they have high levels of bargaining authority. This typology codes each dimension - business centralization and policy integration - as either being present or absent, and then it generates three 'ideal types' according to lowest or highest scores on these dimensions (Gerring 2007). Observe that this is not an additive index, therefore the components are not supposed to have equal or different weights within it (Gerring, 2007).

Table 2 classifies the main business associations in Latin America according to the two components of our typology of business coordination. One can observe that business asso- 
Table 2: Patterns of Business Coordination in Latin America, 2010

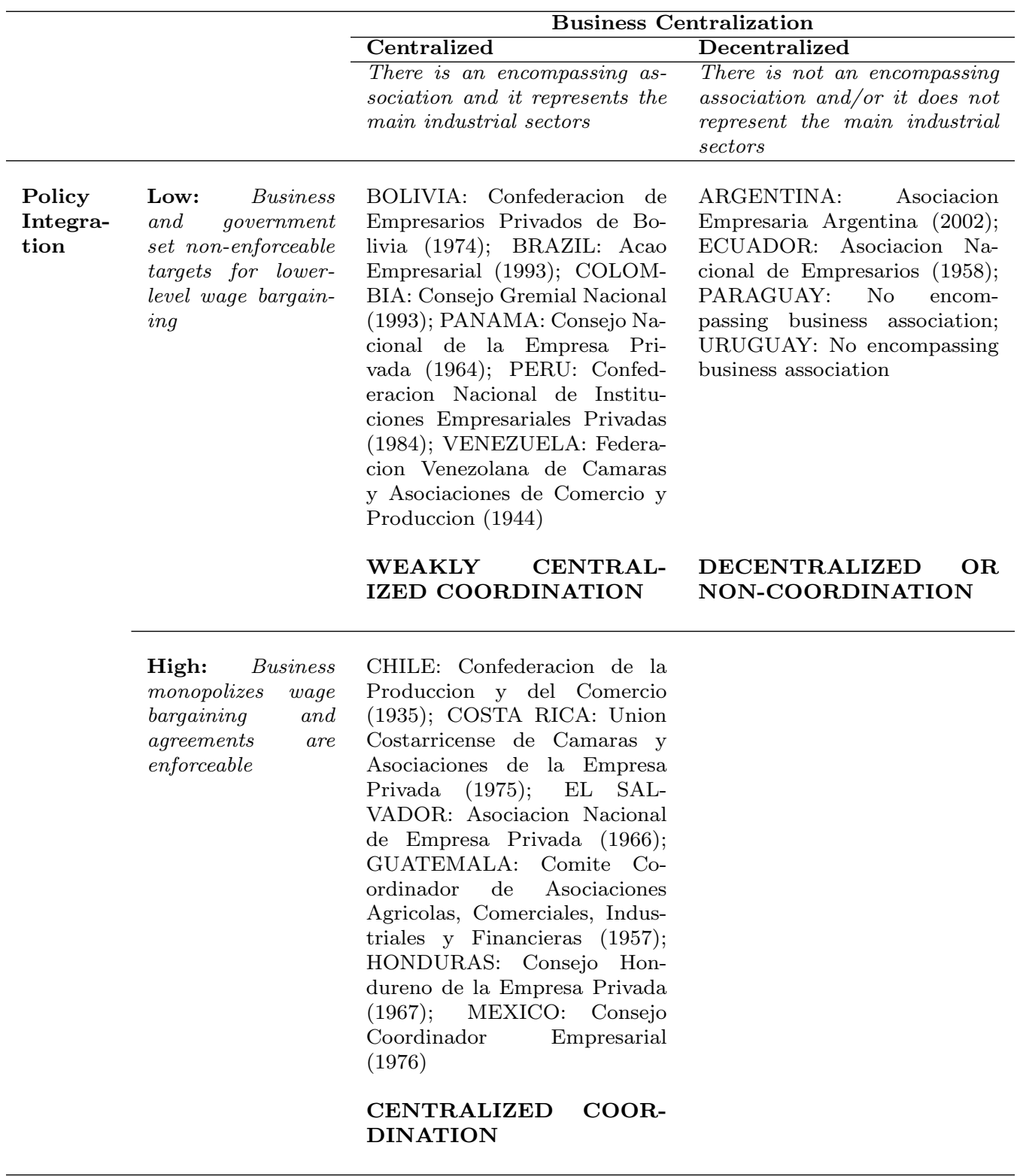


ciations in Argentina, Paraguay, or Uruguay are not centrally coordinated and weakly integrated to the policymaking process (low bargaining authority). Thus, they follow a pattern of decentralized coordination. Business associations are centrally but weakly coordinated in Bolivia, Brazil, Colombia, Panama, Peru and Venezuela; and they are weakly integrated to the policymaking process. Then, they follow a pattern of weakly centralized coordination. Finally, business interest groups are centrally coordinated in Chile, Central America, and Mexico, and are well integrated to the policymaking process. Thus, they follow a pattern of highly centralized coordination.

Therefore, one can expect that business associations in Chile, Mexico or Central America are more influential and consequential for tax policy than their peers in, for example, Argentina, Paraguay, or Uruguay. In other words, governments (especially those with redistributive tax preferences) in the first group of countries will find it more difficult to impose their tax preferences than in the second group of countries.

Lastly, I also considered four possible alternative explanations of the variation in tax policy: industrial concentration, country-level economic performance, size of central government, and lagged trends of fiscal performance. First, I calculated a country-level index of industrial concentration that measures the total share in the national production of the three largest economic sectors as percentage of the GDP. Second, I included three indicators measuring the impact of economic performance at the country-level: economic growth annual rate, GDP per capita (Chain series 2005 US\$), and exchange rate of domestic currency to US dollars. These covariates measure country-specific economic effects and the effects of international financial shocks. Third, I included an indicator of the size of central government: central government consumption share (\% PPP converted GDP per capita). Finally, I incorporated two indicators to assess the impact of past fiscal performance at the country-level: central government debt (as \% of GDP) and primary fiscal balance (as \% of GDP). I also controlled for the effect of the lagged values of these variables and the size of the country. For these indicators, I relied on data provided by the Penn World Table Version 
(Feenstra, Inklaar, and Timmer 2013) and the UN-ECLAC.

\section{Estimation and Results}

Treatment and outcome variables are measured at various points of time (1990-2010) for 18 countries in Latin America. Consequently, I estimated two types of models: cross-sectional fixed-effects and Arellano-Bond dynamic panel estimations. For the panel analysis, the Hausman test suggests that fixed-effects models are more suitable than random-effects models. Fixed-effect models not only allow us to explore the relationship between the patterns of business coordination and tax policy over time, but also to evaluate the impact of withincountry characteristics on predictor variables. Lagrange multiplier and serial correlation tests indicated the possible presence of serial correlation problems, so all the models were also corrected for serial correlation in the error term.

The inclusion of lagged dependent variables in time-series cross-sectional models is a subject of intense debate in political science (Achen 2000; Beck and Katz 2011; Plumper, Troeger, and Manow 2005). For this reason, I used a different approach to model dynamic data generating processes and ran Arellano-Bond GMM estimators. The Arellano-Bond dynamic-panel analysis is convenient because the lagged dependent variables are specified as GMM instruments and all available lags are used as separate instruments. This strategy not only help us to avoid any problems of finite sample approximation to the distribution of the estimators, but it also allows us to account for time dynamics and unit-level heterogeneity (Arellano and Bond 1991; Wawro 2002).

Table 3 presents the models estimating the effect of the variables of interest on tax policy. Models 1 to 3 estimate regression models for total tax revenue (as \% GDP) including the main explanatory variables and both country and period fixed effects. Model 1 is the baseline model. Model 2 estimates a panel regression with fixed-effects and includes control variables within the specification. As explained above, the lagged dependent variable was not 
included in models 1 and 2 in order to avoid over-specification problems. The effect of lagged values of the dependent variable are evaluated in model 3, which estimates Arellano-Bond dynamic-panel estimators for total tax revenues and use two lags of the dependent variable as instrumental variables. Models 4 and 6 estimate panel regressions with fixed-effects for direct and indirect taxes as \% of total tax revenues. Models 5 and 7 estimate Arellano-Bond dynamic-panel estimators for direct and indirect taxes as \% of total tax revenues.

The results presented in Table 3 confirm the hypothesis that centrally coordinated business interest groups weaken the positive effect that taxer-type agenda-setters have over the general tax burden. In Models 1 through 3, the coefficients that measure the conditional effect of centralized business organization on the agenda-setter's policy preferences are in the theorized direction, statistically significant, and substantially large.

As predicted in the theory section, the agenda-setter's first-mover advantage in policymaking is diluted as business interests are increasingly coordinated and integrated to the policymaking process. The models suggest that the tax burden increases substantially if the agenda-setters strongly prefer tax increases over spending cuts, but the effect is significantly curtailed as business interest groups are more centrally coordinated and better integrated to policy-making forums. This conditional effect is robust across different model specifications. In fact, the level of significance for the conditional effects over tax policy holds whether we include any combination of time- or country-fixed effects or none at all.

Results presented in Table 3 also show that macroeconomic factors have small or inconsistent effects on tax revenue. Higher levels of industrial concentration negatively impact tax revenue, but this effect disappears when one includes more systematic temporal effects in the model estimation (Model 3). The tax burden only increases marginally as the annual economic growth rate (as \%GDP) increases. The effect of GDP per capita and exchange rates seems to be null. In other words, these estimations suggest that tax revenues are not significantly driven by the fluctuations of the economic cycle.

However, there is strong empirical evidence that previous fiscal performance and alter- 
Table 3: Tax Policy and Business Organization, Latin America 1990-2010

\begin{tabular}{|c|c|c|c|c|c|c|c|}
\hline & $\begin{array}{c}(1) \\
\text { Tax Revenue } \\
F E \\
\text { b/(se) } \\
\end{array}$ & $\begin{array}{c}(2) \\
\text { Tax Revenue } \\
F E \\
\text { b/(se) } \\
\end{array}$ & $\begin{array}{c}(3) \\
\text { Tax Revenue } \\
\text { Dynamic } \\
\text { b/(se) }\end{array}$ & $\begin{array}{c}(4) \\
\text { Direct } \\
F E \\
\mathrm{~b} /(\mathrm{se}) \\
\end{array}$ & $\begin{array}{c}(5) \\
\text { Direct } \\
\text { Dynamic } \\
\text { b/(se) }\end{array}$ & $\begin{array}{c}(6) \\
\text { Indirect } \\
F E \\
\mathrm{~b} /(\mathrm{se}) \\
\end{array}$ & $\begin{array}{c}(7) \\
\text { Indirect } \\
\text { Dynamic } \\
\mathrm{b} /(\mathrm{se})\end{array}$ \\
\hline Taxer Agenda-Setter & $\begin{array}{c}3.358^{* * *} \\
(0.71)\end{array}$ & $\begin{array}{c}3.317^{* * *} \\
(0.53)\end{array}$ & $\begin{array}{c}1.271^{* * *} \\
(0.43)\end{array}$ & $\begin{array}{c}4.638^{* * *} \\
(1.75)\end{array}$ & $\begin{array}{l}2.358 \\
(1.59)\end{array}$ & $\begin{array}{c}-5.050^{*} \\
(2.05)\end{array}$ & $\begin{array}{l}-2.473 \\
(1.85)\end{array}$ \\
\hline Partisan Power & $\begin{array}{c}-0.013^{+} \\
(0.01)\end{array}$ & $\begin{array}{c}0.011^{+} \\
(0.01)\end{array}$ & $\begin{array}{l}0.000 \\
(0.01)\end{array}$ & $\begin{array}{c}-0.058^{* * *} \\
(0.02)\end{array}$ & $\begin{array}{l}-0.015 \\
(0.02)\end{array}$ & $\begin{array}{l}0.031 \\
(0.02)\end{array}$ & $\begin{array}{l}0.025 \\
(0.02)\end{array}$ \\
\hline Business Coordination & $\begin{array}{l}2.680 \\
(0.63)\end{array}$ & $\begin{array}{c}2.971 \\
(0.79)\end{array}$ & $\begin{array}{l}2.065 \\
(0.65)\end{array}$ & $\begin{array}{l}1.103 \\
(2.59)\end{array}$ & $\begin{array}{c}1.131 \\
(2.29)\end{array}$ & $\begin{array}{l}-1.344 \\
(3.02)\end{array}$ & $\begin{array}{c}-1.680 \\
(2.83)\end{array}$ \\
\hline Taxer*Coordination & $\begin{array}{c}-0.988^{* * *} \\
(0.27)\end{array}$ & $\begin{array}{c}-0.593^{* * *} \\
(0.22)\end{array}$ & $\begin{array}{c}-0.522^{* * *} \\
(0.17)\end{array}$ & $\begin{array}{c}-2.039^{* * *} \\
(0.73)\end{array}$ & $\begin{array}{c}-1.104^{+} \\
(0.62)\end{array}$ & $\begin{array}{c}1.631^{+} \\
(0.85)\end{array}$ & $\begin{array}{l}0.892 \\
(0.76)\end{array}$ \\
\hline Taxer*Partisan & $\begin{array}{r}-0.749 \\
(1.17)\end{array}$ & $\begin{array}{c}-3.982^{* * *} \\
(0.92)\end{array}$ & $\begin{array}{r}-0.614 \\
(0.74)\end{array}$ & $\begin{array}{r}-0.465 \\
(3.01)\end{array}$ & $\begin{array}{r}-1.493 \\
(2.64)\end{array}$ & $\begin{array}{l}2.780 \\
(3.52)\end{array}$ & $\begin{array}{l}2.838 \\
(3.15)\end{array}$ \\
\hline L1.Tax Revenue & & & $\begin{array}{c}0.680^{* * *} \\
(0.05)\end{array}$ & & & & \\
\hline L1.Direct Taxes & & & & & $\begin{array}{c}0.503^{* * *} \\
(0.05)\end{array}$ & & \\
\hline L1.Indirect Taxes & & & & & & & $\begin{array}{c}0.653^{* * *} \\
(0.05)\end{array}$ \\
\hline Industrial Concentration & & $\begin{array}{c}-0.157^{* * *} \\
(0.04)\end{array}$ & $\begin{array}{l}0.014 \\
(0.04)\end{array}$ & $\begin{array}{l}-0.024 \\
(0.13)\end{array}$ & $\begin{array}{l}-0.035 \\
(0.13)\end{array}$ & $\begin{array}{l}0.039 \\
(0.16)\end{array}$ & $\begin{array}{l}0.242 \\
(0.16)\end{array}$ \\
\hline Economic Growth & & $\begin{array}{l}0.049 \\
(0.05)\end{array}$ & $\begin{array}{l}0.036 \\
(0.03)\end{array}$ & $\begin{array}{l}0.015 \\
(0.15)\end{array}$ & $\begin{array}{c}-0.228^{+} \\
(0.12)\end{array}$ & $\begin{array}{r}-0.122 \\
(0.18)\end{array}$ & $\begin{array}{c}0.240^{+} \\
(0.14)\end{array}$ \\
\hline L1.Economic Growth & & $\begin{array}{l}0.005 \\
(0.02)\end{array}$ & $\begin{array}{l}-0.015 \\
(0.01)\end{array}$ & $\begin{array}{l}-0.073 \\
(0.07)\end{array}$ & $\begin{array}{l}0.027 \\
(0.06)\end{array}$ & $\begin{array}{l}0.107 \\
(0.08)\end{array}$ & $\begin{array}{l}0.025 \\
(0.06)\end{array}$ \\
\hline GDP per capita & & $\begin{array}{r}-0.000 \\
(0.00)\end{array}$ & $\begin{array}{l}0.000 \\
(0.00)\end{array}$ & $\begin{array}{l}0.000 \\
(0.00)\end{array}$ & $\begin{array}{l}0.002 \\
(0.00)\end{array}$ & $\begin{array}{l}0.001 \\
(0.00)\end{array}$ & $\begin{array}{l}-0.002 \\
(0.00)\end{array}$ \\
\hline L1.GDP per capita & & $\begin{array}{l}0.000 \\
(0.00)\end{array}$ & $\begin{array}{r}-0.000 \\
(0.00)\end{array}$ & $\begin{array}{l}0.002 \\
(0.00)\end{array}$ & $\begin{array}{c}-0.002 \\
(0.00)\end{array}$ & $\begin{array}{c}-0.003 \\
(0.00)\end{array}$ & $\begin{array}{l}0.002 \\
(0.00)\end{array}$ \\
\hline Exchange Rate & & $\begin{array}{l}0.000 \\
(0.00)\end{array}$ & $\begin{array}{l}0.000 \\
(0.00)\end{array}$ & $\begin{array}{l}0.003 \\
(0.00)\end{array}$ & $\begin{array}{l}0.001 \\
(0.00)\end{array}$ & $\begin{array}{l}0.001 \\
(0.00)\end{array}$ & $\begin{array}{r}-0.001 \\
(0.00)\end{array}$ \\
\hline L1.Exchange Rate & & $\begin{array}{l}-0.001 \\
(0.00)\end{array}$ & $\begin{array}{r}-0.000 \\
(0.00)\end{array}$ & $\begin{array}{c}-0.004^{* * *} \\
(0.00)\end{array}$ & $\begin{array}{c}-0.002^{+} \\
(0.00)\end{array}$ & $\begin{array}{l}0.003 \\
(0.00)\end{array}$ & $\begin{array}{l}0.002 \\
(0.00)\end{array}$ \\
\hline Govt. Consumption & & $\begin{array}{c}-0.004 \\
(0.16)\end{array}$ & $\begin{array}{l}0.151 \\
(0.12)\end{array}$ & $\begin{array}{c}-0.624 \\
(0.51)\end{array}$ & $\begin{array}{c}0.121 \\
(0.43)\end{array}$ & $\begin{array}{c}-0.444 \\
(0.60)\end{array}$ & $\begin{array}{c}-0.010 \\
(0.52)\end{array}$ \\
\hline L1.Govt. Consumption & & $\begin{array}{l}0.031 \\
(0.15)\end{array}$ & $\begin{array}{r}-0.116 \\
(0.11)\end{array}$ & $\begin{array}{l}0.658 \\
(0.49)\end{array}$ & $\begin{array}{l}0.378 \\
(0.39)\end{array}$ & $\begin{array}{l}0.065 \\
(0.57)\end{array}$ & $\begin{array}{l}0.034 \\
(0.46)\end{array}$ \\
\hline Primary Fiscal Balance & & $\begin{array}{c}0.234^{* * *} \\
(0.05)\end{array}$ & $\begin{array}{c}0.244^{* * *} \\
(0.03)\end{array}$ & $\begin{array}{c}0.583^{* * *} \\
(0.16)\end{array}$ & $\begin{array}{c}0.750^{* * *} \\
(0.13)\end{array}$ & $\begin{array}{c}-0.589^{* * *} \\
(0.19)\end{array}$ & $\begin{array}{c}-0.737^{* * *} \\
(0.15)\end{array}$ \\
\hline L1.Primary Fiscal Bal. & & $\begin{array}{c}0.096^{*} \\
(0.05)\end{array}$ & $\begin{array}{c}-0.052 \\
(0.04)\end{array}$ & $\begin{array}{c}0.307^{+} \\
(0.16)\end{array}$ & $\begin{array}{l}0.025 \\
(0.12)\end{array}$ & $\begin{array}{c}-0.376^{*} \\
(0.18)\end{array}$ & $\begin{array}{l}0.043 \\
(0.14)\end{array}$ \\
\hline Government Debt & & $\begin{array}{c}-0.016^{* * *} \\
(0.01)\end{array}$ & $\begin{array}{c}-0.007^{+} \\
(0.00)\end{array}$ & $\begin{array}{l}0.012 \\
(0.02)\end{array}$ & $\begin{array}{l}-0.019 \\
(0.02)\end{array}$ & $\begin{array}{l}-0.004 \\
(0.02)\end{array}$ & $\begin{array}{l}0.024 \\
(0.02)\end{array}$ \\
\hline L1.Government Debt & & $\begin{array}{r}-0.001 \\
(0.01)\end{array}$ & $\begin{array}{l}0.002 \\
(0.00)\end{array}$ & $\begin{array}{c}-0.038^{*} \\
(0.02)\end{array}$ & $\begin{array}{l}0.011 \\
(0.01)\end{array}$ & $\begin{array}{l}0.016 \\
(0.02)\end{array}$ & $\begin{array}{c}-0.004 \\
(0.02)\end{array}$ \\
\hline Country Size & & $\begin{array}{c}8.515^{* * *} \\
(1.30)\end{array}$ & $\begin{array}{l}2.751^{*} \\
(1.15)\end{array}$ & $\begin{array}{c}18.851^{* * * *} \\
(4.28)\end{array}$ & $\begin{array}{c}14.444^{* * *} \\
(3.89)\end{array}$ & $\begin{array}{l}-5.533 \\
(4.99)\end{array}$ & $\begin{array}{l}-7.190 \\
(4.50)\end{array}$ \\
\hline $\begin{array}{l}N \\
R^{2}\end{array}$ & $\begin{array}{c}369 \\
0.221\end{array}$ & $\begin{array}{c}335 \\
0.579\end{array}$ & 317 & $\begin{array}{c}335 \\
0.540\end{array}$ & 316 & $\begin{array}{c}335 \\
0.410\end{array}$ & 316 \\
\hline
\end{tabular}

$+p<0.10,{ }^{*} p<0.05,{ }^{* * *} p<0.01$ 
native funding tools are somewhat important to explain variation in tax revenue. First, tax revenues increase significantly when central government experienced fiscal stress in the previous period. And second, our estimations suggest that there is a trade-off between issuing debt and raising tax revenues. As one could reasonably expect, central governments seem to reduce the general tax burden as issuing debt becomes more affordable.

Having found that the effect of agenda-setters' preferences over tax policy outcomes is significantly curtailed by business coordination, now we need to analyze how this conditional relationship shapes the trade-off between direct and indirect taxation. As discussed in the theoretical framework, business community not only has preferences over the general tax burden but also over the type of taxation. Usually business interest groups are more concerned about what type of taxes might be raised than about the general tax burden. For example, business interest groups usually agree that fiscal balance is important to keep macroeconomic stability, but they generally prefer the government to fund its activities with taxes that do not affect investment and productivity. If taxes should be raised, business interests would generally prefer to increase indirect taxation.

Models 4 through 7 in Table 3 evaluate whether or not the patterns of business coordination shape the trade-off between direct and indirect taxation. These models support the hypothesis that indirect taxation increases as business interest groups become more centrally coordinated and integrated to the policymaking process. If business interest groups are centrally coordinated around encompassing associations, the cost of financing central government?s activities is more likely to be transferred to consumers or citizens - who are not well organized for collective action, or are not well represented in legislative bodies. Models 4 to 7 also show that, as expected, the type of agenda-setter has substantial effects on the tax structure. Direct taxes (as \% total tax revenues) increase by $14 \%$ and indirect taxes (as $\%$ total tax revenues) decrease by $20 \%$ if the agenda setter is a taxer-type (in contrast with a non-taxer agenda-setter). However, this effect is curtailed if the business community is highly coordinated and well integrated to the policymaking process. 
The conditional effect between agenda-setters' policy preferences and business coordination is statistically significant and its magnitude substantial. Direct taxes increase about $4 \%$ (as \% of total tax revenues) if the agenda-setter is a taxer-type, but the effect drops by nearly $2 \%$ for every increase in the scale of business coordination. Similarly, indirect taxes decrease about $5 \%$ of total tax revenues if the agenda-setter is a taxer-type, but they increase nearly $1.6 \%$ for every additional point in the scale of business coordination.

Based on the results presented in Table 3, I computed the marginal effects of the agendasetters' preferences when the moderating variable (business coordination) is held constant at different combinations of high, medium, and low values. Figure 1 illustrates these linear combinations and the interaction effect between agenda-setter type and business coordination. Panel (a) illustrates the interaction effect for tax revenues (as \% GDP); panel (b) shows the interaction effect for direct taxes (as \% total tax revenues); and panel (c) shows the interaction effect for indirect taxes (as \% total tax revenues). These marginal effects correspond to the first derivative of different tax outcomes with respect to the agenda-setters' policy preferences at different levels of business coordination and holding partisan powers constant at $66 \%$. Consequently, the estimated marginal effects assess whether or not the effect of agenda-setters' policy preferences is curtailed as we introduce changes in the degree of business coordination.

The theoretical model predicts that the effect of taxer-type agenda-setters would slow down, as business interest groups are better coordinated and integrated to the policy-making process. It also predicts that the presence of centrally coordinated business interest groups will provide strong incentives for the governments to privilege indirect taxation as the main source of tax revenue. Panels (a) to (c) in Figure 1 are broadly consistent with these expectations in demonstrating that business coordination curtails the effect of taxer-type agenda-setters in the predicted directions. Panels (a) to (c) in Figure 1 also show that the effect of the first-mover's policy preferences (presidents and finance ministers) decreases substantially as the level of business coordination increases. 

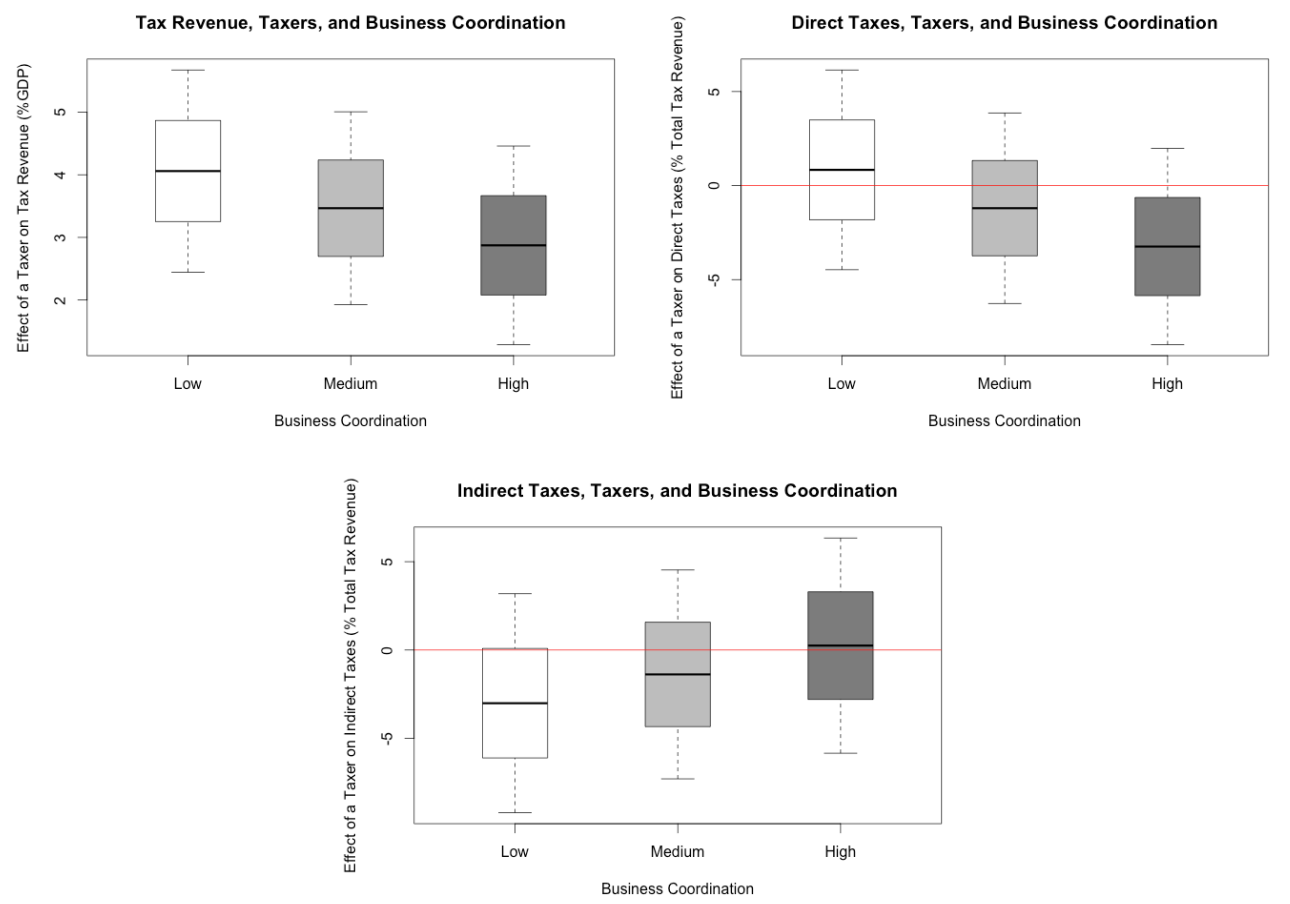

Figure 1: Joint Effects Agenda-Setters' Preferences and Business Coordination

Whiskers mark the $95 \%$ confidence intervals cut-offs. Partisan powers were fixed at $66 \%$ for the calculation of linear combinations. Linear calculations were calculated based on Table 3, model 2 , models 2,4 , and 6 . 
Figure 1 also presents strong evidence that total tax revenues and direct tax revenues decrease as business interest groups become better coordinated - panels (a) and (b) -, and the variation in business coordination shapes the policy trade-off between direct and indirect taxation - panels (b) and (c). As business interest groups become better coordinated, indirect taxation prevails over direct taxation (especially corporate taxes) as the main policy tool to fund government spending. Consequently, business interest groups' policy preferences and their organizational capacity seem to effectively shape fiscal policy choices.

\section{Robustness Checks}

In order to test the robustness of the results presented in the previous section, I tested the models for the presence significant outliers or influential observations. In particular, I looked for substantial differences between predicted (based on the fixed-effects regressions) and observed values. The presence of observations with large residuals would suggest sample peculiarities or data errors. A simple leverage analysis allows us to observe if the values of the coefficients deviate from their mean and if those "high leverage" points have a substantial effect on the estimate. This analysis not only identifies these "high leverage" (or influential) observations, and calculates Cook's distances, but also removes them from the statistical analysis to check if the estimates change significantly.

Figure A-1 in the Appendix shows leverage versus the squared residuals for the fixedeffects regression models explaining tax revenues, and the trade-off between direct and indirect taxation. In the upper panel, one can observe that there are several outlier observations in the model for tax revenues. In particular, some observations for Venezuela (1990, 1997, 2010), Bolivia (1996, 2006, 2007, 2008), and Ecuador (2010) have either high leverage or large residuals. The leverage analysis for the model on direct taxation also identifies some outlier observations: Venezuela 1996-1998; Guatemala 1991; Colombia 1990, 1992. There are some similar outlier observations in the model for indirect taxation (Paraguay 1991; Venezuela1991, 1996, 1998). The leverage analysis presented in Figure A-1 in the Appendix 
also suggests that there are some countries that could potentially distort the statistical analysis. Interestingly, most of the outlier observations correspond to countries with economies that depend highly on natural resources revenues. In fact, Figure A-1 shows that observations for Venezuela (in different years) have either high leverage or large residuals.

I calculated Cook's D values for these outlier observations and found out that they are high but never larger than 1 (the rule of thumb for robust regression techniques is that we should exclude values higher than 1 from the robust regression analysis), which suggests that these values are not very influential. Nevertheless, I dropped observations with either high leverage or large residuals and ran the fixed-effects models again in order to check if the statistical results hold up. Results are presented in Table A-1 in the Appendix (first three models).

The results are quite compelling. If we exclude Venezuela, the differences between predicted and observed values are minimal. The effects of the main variables of interest and the interaction term are still significant and are in the expected direction. In fact, the models 1 through 6 in Table A-1 in the Appendix show that centralized patterns of business coordination downgrade the effect of taxer-type agenda-setters on tax policy. These models are still well fitted even after we dropped a substantial number of observations. These results are also quite consistent even when certain periods or certain countries (potential outliers) are removed from the statistical analysis and when estimators are corrected for serially correlation in Model 3.

\section{Endogeneity Issues}

The previous analysis finds empirical support for the hypothesis concerning to the role of the domestic models of business organization in shaping tax policy. However, the characteristics and dynamics of the explanatory variables might raise questions about endogeneity.

One might reasonably argue that the effect of business coordination on tax policy outcomes could be enhanced by previously implemented tax policies that could benefit or hurt busi- 
ness interest groups by improving or damaging their internal coordination. In other words, there are reasons to believe that the independent variables could be potentially related to unobserved determinants of the outcome variable.

There are several ways to deal with endogeneity, but most of them are focused on the use of instrumental variables to replace the problematic independent variable with a proxy variable that is uncontaminated by error or unobserved factors that affect the outcome (Sovey and Green 2011, 188). The rationale is straightforward: if some independent variables are systematically related to unobserved causes of the outcome variables (two-way causation problem), then one needs to estimate those independent variables as a function of instrumental (exogenous) variables, generate predicted values of the independent variables, and estimate the outcomes variables based on those predicted values. These instrumental variables could be random or "plausibly" random factors that are unrelated to the unmeasured causes of the outcome variables (Sovey and Green 2011, 190).

The procedure consists of two-stage estimations. In the first stage, the results of the regression are used to generate predicted values for the endogenous variables. In the second stage, the endogenous variables can be replaced by their predicted values. It is reasonable to think that the implementation of any tax policy could affect the domestic levels of business coordination. For example, if recent tax policies privileged corporate taxation over indirect taxation, one might expect that business associations saw their organizational capacity undermined because firms and sectorial business associations would redirect their resources to lobbying activities aimed to protect particularistic interest rather than broad, collective interest. These strategic responses would weaken the encompassing business associations? ability to coordinate cross-sectorial actions. Consequently, it is plausible that tax policies and business coordination are simultaneously determined.

In order to tackle this methodological problem, I estimated an instrumental-variable regression using the age of encompassing business associations (since their date of creation) as the instrumental variable for business coordination. This choice has several advantages. 
Table 4: Instrumental Variables Regression

\begin{tabular}{|c|c|c|c|}
\hline \multicolumn{4}{|c|}{ First Stage Regression } \\
\hline & $(1)$ & $(2)$ & $(3)$ \\
\hline & Tax Revenue & Direct Taxes & Indirect Taxes \\
\hline & $\mathrm{b} /(\mathrm{se})$ & $\mathrm{b} /(\mathrm{se})$ & $\mathrm{b} /(\mathrm{se})$ \\
\hline \multirow[t]{2}{*}{ Age } & $0.022^{* * *}$ & & \\
\hline & $(0.01)$ & & \\
\hline \multicolumn{4}{|c|}{ Instrumental variables (2SLS) regression } \\
\hline \multirow{5}{*}{ Taxer Agenda-Setter } & $(1)$ & $(2)$ & (3) \\
\hline & Tax Revenue & Direct Taxes & Indirect Taxes \\
\hline & $\mathrm{b} /(\mathrm{se})$ & $\mathrm{b} /(\mathrm{se})$ & $\mathrm{b} /(\mathrm{se})$ \\
\hline & $2.537^{* * *}$ & -0.084 & 1.458 \\
\hline & $(0.32)$ & $(1.02)$ & $(1.04)$ \\
\hline \multirow[t]{2}{*}{ Partisan Powers } & $0.035^{* * *}$ & 0.029 & -0.038 \\
\hline & $(0.01)$ & $(0.03)$ & $(0.03)$ \\
\hline \multirow[t]{2}{*}{ Business Coordination } & $-0.948 * * *$ & 0.045 & 1.400 \\
\hline & $(0.36)$ & $(1.15)$ & $(1.17)$ \\
\hline$N$ & 353 & 352 & 352 \\
\hline$R^{2}$ & & & \\
\hline
\end{tabular}

First, this indicator is correlated with the endogenous independent variable (business coordination), but it is uncorrelated with the endogenous dependent variable (tax policy outcomes). Second, there is a positive correlation between the age of the encompassing business associations and the degree of business coordination, thus it passes one key requirement for being a good instrument (Sovey and Green 2011, 190). Third, the age of encompassing business associations is independent of the error term. And finally, the age of encompassing business associations strongly predicts the degree of business coordination after controlling for covariates. Consequently, the age of encompassing business associations is both relevant and exogenous, which are the main conditions for being a good instrument.

The results presented in Table 4 suggest that the age of encompassing business associations is highly and significantly correlated with business coordination. In the first-stage regressions, the age of encompassing business associations has a positive and significant effect on business coordination. The estimators resulting from the instrumental variables (2SLS) 
regression models remain consistent with the results presented in Table 3 and Table A-1: the non-conditional effect of business coordination is not significant, but its conditional effect remains statistically significant (except for indirect taxes). Therefore, our estimators are not only consistent across different model specifications, but also across different tests for influential cases and endogeneity issues.

\section{Concluding Remarks}

Much of the debate about fiscal policy-making has focused on the effect of institutional settings on policy outcomes. The role of economic or political actors is rarely in the center of the debate. Surprisingly, this is particularly true in the case of business interest groups and the crucial role that firms and business organizations play in fiscal (economic) policy. While scholars and pundits maintain that money buys influence or that business interest groups have hijacked democratic governments, there have been very few attempts to understand the mechanisms that effectively translate business political influence into specific policy outcomes. This paper highlights the importance of the organizational attributes of business interest groups for the analysis of tax policy-making.

The empirical analysis presented in this article sought to demonstrate that business interest groups are key actors in the fiscal policymaking process and they shape agendasetters' ability to successfully enact raising-revenues tax reforms. This article presents strong empirical evidence that business interest groups have a preponderant role for the definition of the general tax burden and the selection of different tax policy tools in Latin America. However, their role is reactive rather than proactive. Encompassing business associations, industry-level association, conglomerates, and firms display their power of influence only when the agenda-setter strongly prefers to increase taxes over cut expenditures (taxer-type) as his optimal fiscal strategy. Thus, centrally coordinated business interest groups always curtail the effect of taxer-type agenda-setters on tax policy outcomes. 
The empirical evidence shown in this article supports the theoretical claim that general and direct tax collection will decrease as business interest groups become more powerful and organized, even when agenda-setters strongly prefer to increase taxes. Additionally, this article provides empirical evidence that indirect taxation will substantially increase if the business interest groups are centrally coordinated, even their preferences clash with those of the agenda-setter.

Therefore, this article offers a comprehensive empirical argument to analyze the politics of tax reform. In particular, I present strong empirical evidence that successful tax reforms will not only depend on the bargaining between the executive and the legislative branches of government, but also on the characteristics of non-institutional veto players and their capacity to spend resources for influencing the fiscal policymaking process. This article also offers an innovative way to analyze and measure the sources of the business interest groups? power of influence. It not only offers a new theoretical approach but also new methodological tools to understand how business interest groups are actually influential for policymaking process. 


\section{References}

[1] Achen, C. (2000) Why Lagged Dependent Variables Can Supress the Explanatory Power of Other Independent Variables, Presented at the Annual Meeting of Political Methodology.

[2] Alesina, A. and Drazen, A. (1991) Why are Stabilizations Delayed?, The American Economic Review, 81(5), 117088.

[3] Alesina, A. F., Carloni, D. and Lecce, G. (2011) The Electoral Consequences of Large Fiscal Adjustments (Working Paper No. 17655). National Bureau of Economic Research.

[4] Alesina, A. and Rosenthal, H. (1995) Partisan Politics, Divided Government, and the Economy. New York NY: Cambridge University Press.

[5] Alt, J., Preston, I. and Sibieta, L. (2010) The Political Economy of Tax Policy, in J. A. Mirrlees (ed.), Dimensions of Tax Design: The Mirrlees Review. Oxford: Oxford University Press.

[6] Arellano, M. and Bond, S. (1991) Some Tests of Specification for Panel Data: Monte Carlo Evidence and an Application to Employment Equations, The Review of Economic Studies, 58(2), 27797.

[7] Bartlett, R. (1973) Economic Foundations of Political Power. New York: Free Press.

[8] Beck, N. and Katz, J. N. (2011) "Modeling Dynamics in Time-Series-Cross-Section Political Economy Data", Annual Review of Political Science, 14, 33152.

[9] Boix, C. (1998) Political Parties, Growth, and Inequality. New York: Cambridge University Press.

[10] Carstens, A. and Jacome, L. I. (2005) The 1990s Institutional Reform of Monetary Policy in Latin America, Working Papers Central Bank of Chile, December(343). 
[11] Castañeda, Néstor and David Doyle. (2015). "Redistribution and taxation: how business and informal labor shape partisan tax strategies?". Working paper.

[12] Coen, D., Grant, W. and Wilson, G. (2010) Political Science Perspectives on Business and Government, in D. Coen, W. Grant and G. Wilson (eds.), The Oxford Handbook of Business and Government. New York: Oxford University Press.

[13] Collier, P. and Venables, A. J. (2011) Plundered Nations?: Successes and Failures in Natural Resource Extraction. Palgrave Macmillan.

[14] Coppedge, M. (1997) A Classification of Latin American Political Parties, Kellogg Institute Working Paper No. 244

[15] Cox, G. W. and McCubbins, M. D. (2005) Setting the Agenda: Responsible Party Government in the U.S. House of Representatives. New York NY: Cambridge University Press.

[16] Culpepper, Pepper (2011) Quiet Politics and Business Power: Corporate Control in Europe and Japan. New York NY: Cambridge University Press.

[17] Feenstra, R., Inklaar, R. and Timmer, M. (2013) The Next Generation of the Penn World Table, .

[18] De Figueiredo, J. M. and Ritcher, B. (2013) Advancing the empirical research on lobbying, NBER Working Papers, 19698.

[19] Fisher, P. (2009) The Politics of Taxing and Spending. Boulder CO: Lynne Rienner Publishers.

[20] Gerring, J. (2007) Case Study Research: Principles and Practices. Cambridge UK: Cambridge University Press.

[21] Grossman, G. M. (2002) Special Interest Politics. Cambridge, Mass.: The MIT Press. 
[22] Hallerberg, M., Scartascini, C. and Stein, E. (2009) The Budget Process as a Political Arena, in M. Hallerberg, C. Scartascini and E. Stein (eds.), Who Decides the Budget?: A Political Economy Analysis of the Budget Process in Latin America. Washington DC: Harvard University Press

[23] Hall, P. A. and Soskice, D. W. (2001) Varieties of Capitalism: The Institutional Foundations of Comparative Advantage. Oxford UK: Oxford University Press.

[24] Hart, A. (2010) Death of the Partisan? Globalization and Taxation in South America, 1990-2006, Comparative Political Studies, 43(3), 30428.

[25] Hettich, W. and Winer, S. L. (1988) Economic and Political Foundations of Tax Structure, The American Economic Review, 78(4), 70112.

[26] Huber, E., Stephens, J., Mustillo, T. and Pribble, J. (2012) Latin America and the Caribbean Political Dataset 1945-2008, University of North Carolina.

[27] Iversen, T. (1999) Contested Economic Institutions: The Politics of Macroeconomics and Wage Bargaining in Advanced Democracies. Cambridge MA: Cambridge University Press.

[28] Johnson, G. B. and Crisp, B. F. (2003) Mandates, Powers, and Policies, American Journal of Political Science, 47(1), 12842.

[29] Lindblom, C. E. (1977) Politics and markets: the worlds political economic systems. New York: Basic Books.

[30] Mahon, J. E., Jr. (2004) Causes of Tax Reform in Latin America, 1977-95, Latin American Research Review, 39(1), 330.

[31] Mainwaring, S. (1993) Presidentialism, Multipartism, and Democracy, Comparative Political Studies, 26(2), 198228. 
[32] Mainwaring, S. and Shugart, M. S. (1997) Presidentialism and Democracy in Latin America, Reprint. Cambridge UK: Cambridge University Press.

[33] Martin, C. J. (1991) Shifting the Burden: The Struggle over Growth and Corporate Taxation. Chicago: University of Chicago Press.

[34] Martin, C. J. and Swank, D. (2004) Does the Organization of Capital Matter? Employers and Active Labor Market Policy at the National and Firm Levels, The American Political Science Review, 98(4), 593611.

[35] Martin, C. J. and Swank, D. (2012) The Political Construction of Business Interests: Coordination, Growth, and Equality. New York: Cambridge Unversity Press.

[36] Miliband, R. (1969) The state in capitalist society. New York: Basic Books.

[37] Murillo, M. V. (2001) Labor Unions, Partisan Coalitions, and Market Reforms in Latin America. Cambridge, UK; New York, NY, USA: Cambridge University Press.

[38] Murillo, V., Oliveros, V. and Vaishnav, M. (2010) Dataset on Political Ideology of Presidents and Parties in Latin America, Columbia University.

[39] Pérez-Liñán, A. (2013) Database of Coalitions and Factions in Latin American Legislatures 1945-2012. .

[40] Persson, T. and Tabellini, G. E. (2003) The Economic Effects of Constitutions. Cambridge MA: The MIT Press.

[41] Plumper, T., Troeger, V. E. and Manow, P. (2005) Panel Data Analysis in Comparative Politics: Linking Method to Theory, European Journal of Political Research, 44(2), 32754 .

[42] Poterba, J. M. and Von Hagen, J. (1999) Fiscal Institutions and Fiscal Performance. Chicago IL: University of Chicago Press. 
[43] Profeta, P. and Scabrosetti, S. (2008) Political Economy Issues of Taxation, in L. Bernardi, A. Barreix, A. Marenzi and P. Profeta (eds.), Tax Systems and Tax Reforms in Latin America. New York: Routledge.

[44] Reinhart, C. M. and Rogoff, K. S. (2011) The Forgotten History of Domestic Debt*, The Economic Journal, 121(552), 31950.

[45] Richter, B. K., Samphantharak, K. and Timmons, J. F. (2009) Lobbying and Taxes, American Journal of Political Science, 53(4), 893909.

[46] Rodden, J. (2006) Hamiltons Paradox: The Promise and Peril of Fiscal Federalism. New York: Cambridge University Press.

[47] Rueda, D. and Pontusson, J. (2000) Wage Inequality and Varieties of Capitalism, World Politics, 52(03), 35083.

[48] Salamon, L. M. and Siegfried, J. J. (1977) Economic Power and Political Influence: The Impact of Industry Structure on Public Policy, The American Political Science Review, 71(3), 102643.

[49] Schick, A. (1980) Congress and Money: Budgeting, Spending, and Taxing. Washington DC: The Urban Institute.

[50] Schneider, B. R. (2013) Hierarchical Capitalism in Latin America: Business, Labor, and the Challenges of Equitable Development. Cambridge University Press.

[51] Smith, W. C., Luna, J. P., Murillo, M. V., Schrank, A., Huber, E., Stephens, J. D., Limongi, F., et al. (2014) Special Section: Political Economy and the Future of Latin American Politics, Latin American Politics and Society, 56(1), 133.

[52] Sovey, A. J. and Green, D. P. (2011) Instrumental Variables Estimation in Political Science: A Readers Guide, American Journal of Political Science, 55(1), 188200. 
[53] Spiller, P. and Tommasi, M. (2007) The Institutional Foundations of Public Policy in Argentina. New York NY: Cambridge University Press.

[54] Stein, E. and Tomassi, M. (2008) Policymaking in Latin America: How Politics Shapes Policies. New York: Inter-American Development Bank.

[55] Steinmo, S. (1989) Political Institutions and Tax Policy in the United States, Sweden, and Britain, World Politics, 41(4), 50035.

[56] Stokes, S. C. (2001) Mandates and Democracy: Neoliberalism by Surprise in Latin America. New York NY: Cambridge University Press.

[57] Swank, D. and Martin, C. J. (2001) Employers and the Welfare State, Comparative Political Studies, 34(8), 889923.

[58] Wawro, G. (2002) Estimating Dynamic Panel Data Models in Political Science, Political Analysis, 10(1), 2548.

[59] Wilson, F. L. (1983) Interest Groups and Politics in Western Europe: The NeoCorporatist Approach, Comparative Politics, 16(1), 10523.

[60] World Bank (2011) Global Development Finance 2012: External Debt of Developing Countries. The World Bank. 


\section{Appendix}

Table A1: Summary statistics

\begin{tabular}{lccccc}
\hline \multicolumn{1}{c}{ Variable } & Mean & Std. Dev. & Min. & Max. & N \\
\hline & & & & & \\
DEPENDENT VARIABLES & & & & & \\
Tax Revenue (\% GDP) & 13.15 & 3.461 & 6.5 & 25 & 369 \\
Direct Taxes (\% total tax revenue) & 32.214 & 13.3 & 9.4 & 88.3 & 375 \\
Indirect Taxes (\% total tax revenue) & 65.235 & 12.869 & 11.7 & 88.100 & 375 \\
Corporate Tax Rate & 29.183 & 6.763 & 0 & 50 & 378 \\
Value-Added Tax Rate & 12.739 & 5.131 & 0 & 23 & 375 \\
& & & & & \\
INDEPENDENT VARIABLES & & & & & \\
Tax Policy Preferences & 0.41 & 0.492 & 0 & 1 & 378 \\
Partisan Powers & 0.523 & 0.165 & 0.1 & 1 & 378 \\
Business Coordination & 1.23 & 0.799 & 0 & 2 & 378 \\
& & & & & \\
ConTrol VARIABLES & & & & & \\
Market Concentration & 49.099 & 6.2 & 33.5 & 62.7 & 378 \\
Country Size (log) & 9.452 & 1.128 & 7.79 & 12.158 & 378 \\
Economic Growth (annual rate) & 3.804 & 3.719 & -10.9 & 18.3 & 378 \\
Primary Fiscal Balance (\%GDP) & 0.587 & 2.273 & -11.5 & 8.800 & 364 \\
Exchange rate (\$US to domestic) & 345.467 & 997.149 & 0 & 6424.3 & 378 \\
Government Consumption (\%GDP) & 9.069 & 5.272 & 3.1 & 38.9 & 378 \\
GDP per capita (\$US) & 6455.843 & 2681.815 & 1750.9 & 12524.8 & 378 \\
Government Debt (\%GDP) & 46.152 & 37.068 & 8.700 & 289.6 & 360 \\
\hline
\end{tabular}


Table A2: Tax Policy and Business Organization, Latin America 1990-2010 (excluding outliers)

\begin{tabular}{|c|c|c|c|c|c|c|}
\hline & $\begin{array}{c}(1) \\
\text { Tax Revenue } \\
\text { (excl. outliers) } \\
\text { b/(se) }\end{array}$ & $\begin{array}{c}(2) \\
\text { Direct Taxes } \\
\text { (excl. outliers) } \\
\text { b/(se) }\end{array}$ & $\begin{array}{c}(3) \\
\text { Indirect Taxes } \\
\text { (excl. outliers) } \\
\text { b/(se) }\end{array}$ & $\begin{array}{c}(4) \\
\text { Tax Revenue } \\
\text { (excl. Vnzla.) } \\
\text { b/(se) }\end{array}$ & $\begin{array}{c}(5) \\
\text { Direct Taxes } \\
\text { (excl. Vnzla.) } \\
\text { b/(se) }\end{array}$ & $\begin{array}{c}(6) \\
\text { Indirect Taxes } \\
\text { (excl. Vnzla) } \\
\text { b/(se) }\end{array}$ \\
\hline Taxer & $\begin{array}{c}2.890^{* * *} \\
(0.49)\end{array}$ & $\begin{array}{l}4.265^{*} \\
(1.76)\end{array}$ & $\begin{array}{c}-4.361^{*} \\
(2.10)\end{array}$ & $\begin{array}{c}3.093^{* * *} \\
(0.52)\end{array}$ & $\begin{array}{c}4.435^{*} \\
(1.87)\end{array}$ & $\begin{array}{c}-5.217^{*} \\
(2.22)\end{array}$ \\
\hline Partisan & $\begin{array}{l}0.007 \\
(0.01)\end{array}$ & $\begin{array}{c}-0.075^{* * *} \\
\quad(0.02)\end{array}$ & $\begin{array}{c}0.052^{*} \\
(0.02)\end{array}$ & $\begin{array}{c}0.010+ \\
(0.01)\end{array}$ & $\begin{array}{c}-0.079^{* * *} \\
(0.02)\end{array}$ & $\begin{array}{l}0.053^{*} \\
(0.02)\end{array}$ \\
\hline Coordination & $\begin{array}{l}1.711^{*} \\
(0.86)\end{array}$ & $\begin{array}{c}-5.681+ \\
(3.14)\end{array}$ & $\begin{array}{l}2.364 \\
(3.72)\end{array}$ & $\begin{array}{c}2.617^{* * *} \\
(0.88)\end{array}$ & $\begin{array}{c}-5.818+ \\
(3.14)\end{array}$ & $\begin{array}{l}2.414 \\
(3.72)\end{array}$ \\
\hline Taxer* Coord. & $\begin{array}{c}-0.445^{*} \\
(0.20)\end{array}$ & $\begin{array}{c}-2.107^{* * *} \\
(0.73)\end{array}$ & $\begin{array}{c}1.197+ \\
(0.87)\end{array}$ & $\begin{array}{c}-0.418^{*} \\
(0.21)\end{array}$ & $\begin{array}{c}-2.113^{* * *} \\
(0.73)\end{array}$ & $\begin{array}{c}1.185+ \\
(0.87)\end{array}$ \\
\hline Taxer*Partisan & $\begin{array}{c}-3.746^{* * *} \\
(0.84)\end{array}$ & $\begin{array}{l}1.675 \\
(3.01)\end{array}$ & $\begin{array}{l}1.123 \\
(3.59)\end{array}$ & $\begin{array}{c}-4.067^{* * *} \\
(0.90)\end{array}$ & $\begin{array}{l}1.324 \\
(3.23)\end{array}$ & $\begin{array}{l}2.724 \\
(3.82)\end{array}$ \\
\hline Concentration & $\begin{array}{c}-0.184^{* * *} \\
(0.04)\end{array}$ & $\begin{array}{l}-0.066 \\
(0.14)\end{array}$ & $\begin{array}{l}0.028 \\
(0.17)\end{array}$ & $\begin{array}{c}-0.192^{* * *} \\
(0.04)\end{array}$ & $\begin{array}{l}-0.059 \\
(0.15)\end{array}$ & $\begin{array}{r}-0.050 \\
(0.18)\end{array}$ \\
\hline Growth & $\begin{array}{l}0.060 \\
(0.04)\end{array}$ & $\begin{array}{l}0.068 \\
(0.15)\end{array}$ & $\begin{array}{l}-0.212 \\
(0.18)\end{array}$ & $\begin{array}{l}0.067 \\
(0.04)\end{array}$ & $\begin{array}{l}0.109 \\
(0.15)\end{array}$ & $\begin{array}{r}-0.210 \\
(0.18)\end{array}$ \\
\hline L1.Growth & $\begin{array}{l}0.009 \\
(0.02)\end{array}$ & $\begin{array}{l}-0.057 \\
(0.07)\end{array}$ & $\begin{array}{l}0.089 \\
(0.09)\end{array}$ & $\begin{array}{l}0.009 \\
(0.02)\end{array}$ & $\begin{array}{l}-0.032 \\
(0.07)\end{array}$ & $\begin{array}{l}0.083 \\
(0.09)\end{array}$ \\
\hline GDP & $\begin{array}{l}-0.000 \\
(0.00)\end{array}$ & $\begin{array}{r}-0.000 \\
(0.00)\end{array}$ & $\begin{array}{l}0.002 \\
(0.00)\end{array}$ & $\begin{array}{r}-0.001 \\
(0.00)\end{array}$ & $\begin{array}{l}-0.001 \\
(0.00)\end{array}$ & $\begin{array}{l}0.002 \\
(0.00)\end{array}$ \\
\hline L1.GDP & $\begin{array}{l}0.001 \\
(0.00)\end{array}$ & $\begin{array}{l}0.003 \\
(0.00)\end{array}$ & $\begin{array}{c}-0.005^{*} \\
(0.00)\end{array}$ & $\begin{array}{l}0.001 \\
(0.00)\end{array}$ & $\begin{array}{c}0.003+ \\
(0.00)\end{array}$ & $\begin{array}{c}-0.005^{*} \\
(0.00)\end{array}$ \\
\hline Exch. Rate & $\begin{array}{l}0.000 \\
(0.00)\end{array}$ & $\begin{array}{c}0.003+ \\
(0.00)\end{array}$ & $\begin{array}{l}0.001 \\
(0.00)\end{array}$ & $\begin{array}{l}0.000 \\
(0.00)\end{array}$ & $\begin{array}{l}0.003 \\
(0.00)\end{array}$ & $\begin{array}{l}0.001 \\
(0.00)\end{array}$ \\
\hline L1.Exch. Rate & $\begin{array}{l}-0.000 \\
(0.00)\end{array}$ & $\begin{array}{c}-0.004^{* * *} \\
(0.00)\end{array}$ & $\begin{array}{l}0.003 \\
(0.00)\end{array}$ & $\begin{array}{l}-0.000 \\
(0.00)\end{array}$ & $\begin{array}{c}-0.004^{*} \\
(0.00)\end{array}$ & $\begin{array}{l}0.003 \\
(0.00)\end{array}$ \\
\hline Govt. Cons. & $\begin{array}{l}0.066 \\
(0.14)\end{array}$ & $\begin{array}{c}-0.826+ \\
(0.50)\end{array}$ & $\begin{array}{l}-0.355 \\
(0.60)\end{array}$ & $\begin{array}{l}0.014 \\
(0.14)\end{array}$ & $\begin{array}{c}-0.845+ \\
(0.51)\end{array}$ & $\begin{array}{l}-0.315 \\
(0.60)\end{array}$ \\
\hline L1.Govt. Cons. & $\begin{array}{l}0.002 \\
(0.13)\end{array}$ & $\begin{array}{l}0.933^{*} \\
(0.47)\end{array}$ & $\begin{array}{l}-0.048 \\
(0.57)\end{array}$ & $\begin{array}{l}-0.011 \\
(0.14)\end{array}$ & $\begin{array}{c}0.934+ \\
(0.49)\end{array}$ & $\begin{array}{l}-0.151 \\
(0.57)\end{array}$ \\
\hline Fiscal Balance & $\begin{array}{c}0.235^{* * *} \\
(0.04)\end{array}$ & $\begin{array}{c}0.447^{* * *} \\
(0.16)\end{array}$ & $\begin{array}{c}-0.379+ \\
(0.20)\end{array}$ & $\begin{array}{c}0.219^{* * *} \\
(0.05)\end{array}$ & $\begin{array}{c}0.404^{*} \\
(0.17)\end{array}$ & $\begin{array}{c}-0.403^{*} \\
(0.20)\end{array}$ \\
\hline L1.Fiscal Bal. & $\begin{array}{c}0.083+ \\
(0.05)\end{array}$ & $\begin{array}{l}0.381^{*} \\
(0.16)\end{array}$ & $\begin{array}{c}-0.532^{* * *} \\
(0.20)\end{array}$ & $\begin{array}{c}0.084+ \\
(0.05)\end{array}$ & $\begin{array}{l}0.348^{*} \\
(0.17)\end{array}$ & $\begin{array}{c}-0.506^{*} \\
(0.20)\end{array}$ \\
\hline Govt. Debt & $\begin{array}{c}-0.014^{* * *} \\
(0.01)\end{array}$ & $\begin{array}{l}0.013 \\
(0.02)\end{array}$ & $\begin{array}{l}-0.010 \\
(0.02)\end{array}$ & $\begin{array}{c}-0.021^{* * *} \\
(0.01)\end{array}$ & $\begin{array}{l}0.012 \\
(0.02)\end{array}$ & $\begin{array}{l}-0.008 \\
(0.02)\end{array}$ \\
\hline L1.Govt. Debt & $\begin{array}{l}-0.001 \\
(0.00)\end{array}$ & $\begin{array}{c}-0.038^{*} \\
(0.02)\end{array}$ & $\begin{array}{l}0.019 \\
(0.02)\end{array}$ & $\begin{array}{l}0.004 \\
(0.01)\end{array}$ & $\begin{array}{c}-0.037+ \\
(0.02)\end{array}$ & $\begin{array}{l}0.016 \\
(0.02)\end{array}$ \\
\hline Country Size & $\begin{array}{c}6.868^{* * *} \\
(1.21)\end{array}$ & $\begin{array}{c}17.671^{* * *} \\
(4.32)\end{array}$ & $\begin{array}{l}-2.254 \\
(5.13)\end{array}$ & $\begin{array}{c}6.707^{* * *} * \\
(1.22)\end{array}$ & $\begin{array}{c}17.226^{* * *} \\
(4.36)\end{array}$ & $\begin{array}{c}-1.702 \\
(5.16)\end{array}$ \\
\hline$N$ & 325 & 313 & 307 & 302 & 302 & 302 \\
\hline$R^{2}$ & 0.599 & 0.579 & 0.445 & 0.611 & 0.583 & 0.449 \\
\hline
\end{tabular}

Estimated with country and year fixed-effects (not shown) 

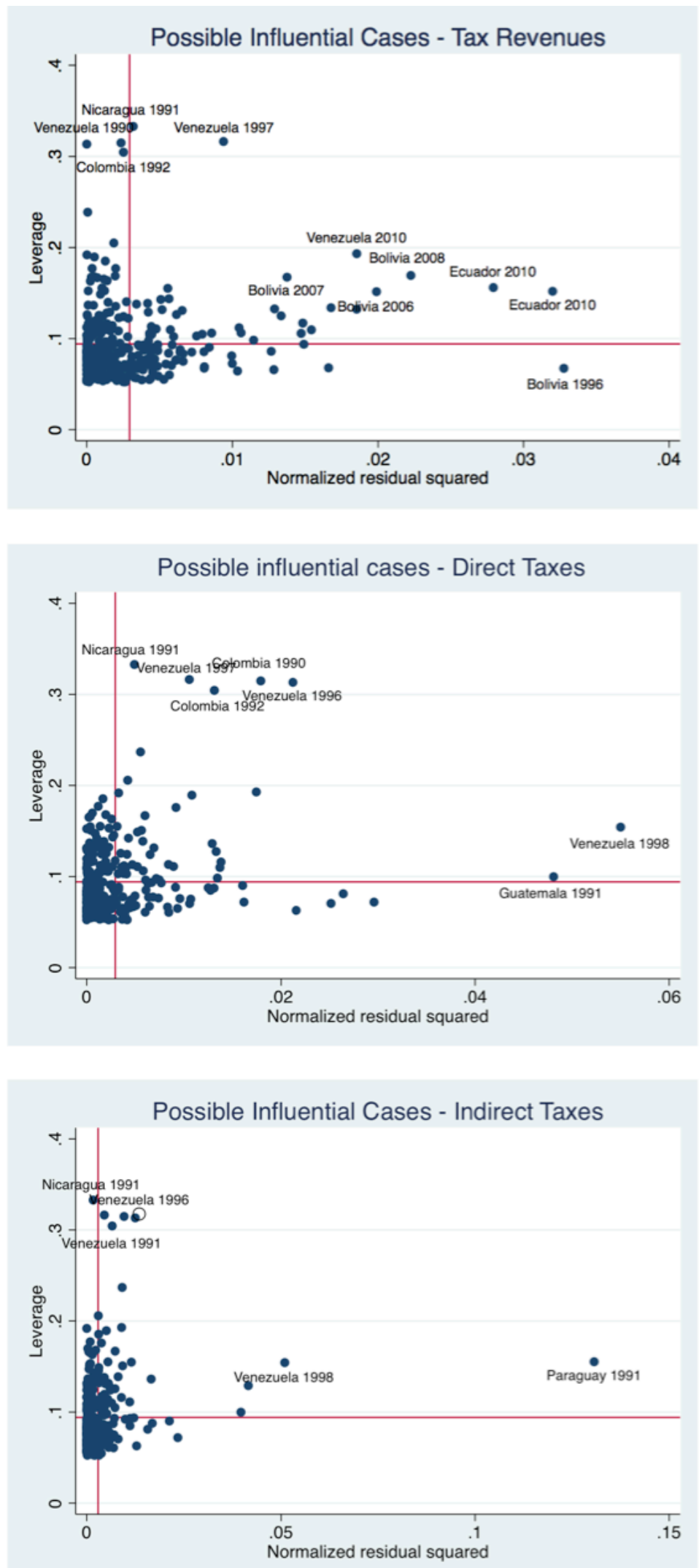

Figure A1: Leverage Analyses to Identify Possible Outliers/Influential Cases 